Article

\title{
Stem Cell Surgery and Growth Factors in Retinitis Pigmentosa Patients: Pilot Study after Literature Review
}

\author{
Paolo Giuseppe Limoli ${ }^{1}\left(\mathbb{D}\right.$, Enzo Maria Vingolo ${ }^{2}{ }^{\mathbb{D}}$, Celeste Limoli $^{1}$ and Marcella Nebbioso ${ }^{2, *}$ \\ 1 Low Vision Research Centre of Milan, p.zza Sempione 3, 20145 Milan, Italy; paololimoli@libero.it (P.G.L.); \\ celeste.limoli@libero.it (C.L.) \\ 2 Department of Sense Organs, Faculty of Medicine and Odontology, Sapienza University of Rome, p.le A. \\ Moro 5, 00185 Rome, Italy; enzomaria.vingolo@uniroma1.it \\ * Correspondence: marcella.nebbioso@uniroma1.it; Tel.: +39-06-49975422; Fax: +39-06-49975425
}

Received: 10 September 2019; Accepted: 26 November 2019; Published: 30 November 2019

check for

\begin{abstract}
To evaluate whether grafting of autologous mesenchymal cells, adipose-derived stem cells, and platelet-rich plasma into the supracoroideal space by surgical treatment with the Limoli retinal restoration technique (LRRT) can exert a beneficial effect in retinitis pigmentosa (RP) patients. Twenty-one eyes underwent surgery and were divided based on retinal foveal thickness (FT) $\leq 190$ or $>190 \mu \mathrm{m}$ into group A-FT and group B-FT, respectively. The specific LRRT triad was grafted in a deep scleral pocket above the choroid of each eye. At 6-month follow-up, group B showed a non-significant improvement in residual close-up visus and sensitivity at microperimetry compared to group A. After an in-depth review of molecular biology studies concerning degenerative phenomena underlying the etiopathogenesis of retinitis pigmentosa (RP), it was concluded that further research is needed on tapeto-retinal degenerations, both from a clinical and molecular point of view, to obtain better functional results. In particular, it is necessary to increase the number of patients, extend observation timeframes, and treat subjects in the presence of still trophic retinal tissue to allow adequate biochemical and functional catering.
\end{abstract}

Keywords: autograft; embryonic stem cells (ESCs); growth factor (GF); hereditary retinal disease; induced pluripotent stem cells (iPSCs); limoli retinal restoration technique (LRRT); mesenchymal stem cell (MSC); retinitis pigmentosa; spectral domain-optical coherence tomography (SD-OCT)

\section{Introduction}

Retinitis pigmentosa (RP) comprises a heterogeneous group of hereditary retinal diseases characterized by progressive degeneration of photoreceptors. It primarily and severely affects the rods, with subsequent involvement of cone functions [1-3].

Although the etiology is quite variable, the ultimate pathway is progressive photoreceptor cell death by apoptosis, with subsequent retinal atrophy. The prevalence of RP is approximately 1:4000, affecting more than 1 million people worldwide [4].

In X-linked patients, who account for approximately $5-15 \%$ of all cases, the phenotype of the disease generally tends to be the most severe. Conversely, patients with autosomal recessive RP, comprising $50-60 \%$ of cases, and patients with autosomal dominant $\mathrm{RP}$, which is responsible for $30-40 \%$ of cases, show a better visual prognosis, slower progression of the disease, and longer maintenance of central vision. A large number of mutations in more than 80 different genes are known to be the major cause of RP [1-4]. 
The etiopathogenesis of RP cannot be explained by genetics alone, because there are other mechanisms that cover various biological aspects: Trophism, oxidation, inflammation, immune response, vascularization, and apoptosis [5].

In the majority of cases, visual impairment usually begins with night blindness and progresses to the restriction of peripheral vision. Macular degeneration usually occurs only at the very end stage of the disease, and may also culminate in the loss of central vision $[1,2,6]$.

The suspect of the disease, caused by visual concerns, can be confirmed by specific examinations, such as visual field testing, full-field electroretinogram (ERG), and optical coherence tomography (OCT) $[7,8]$.

To date, the disease has no curative treatment, but new therapeutic options are being actively developed, involving implanted retinal prosthetic devices, gene therapy, and cell therapy, to replace or restore defective cells [9-12]. Cell preservation is being actively investigated, especially as regards the neurotrophic, antiapoptotic, hemorheologic, and immunomodulatory actions of growth factors (GFs) and cytokines, which can be used directly or in a cell-mediated way, targeting the residual retinal cells [9-15].

The therapeutic aim is to slow down or prevent the death of photoreceptors by delivering embryonic stem cells (ESCs), induced pluripotent stem cells (iPSCs), and mesenchymal stem cells (MSCs) to precise target locations in the eye [16-21].

ESCs, iPSCs, and MSCs are capable of self-renewal and display multipotency, i.e., the ability to differentiate into all cells derived from any of the three germ layers.

MSCs can be obtained from different sources: Umbilical cord, peripheral blood, bone marrow, and adipose tissue [22-24]. They therefore play a key role in organogenesis and remodeling, as well as in tissue repair and reactivation synaptic connections by means of GFs, and can therefore enhance the formation of new functional conditions [24,25]. Other positive aspects are the immunosuppressant function and the inhibition of proinflammatory cytokine release [26-28].

As demonstrated by clinical and preclinical studies, MSC administration does not require immunosuppression, nor does it induce neoplastic transformation; moreover, it is associated with a significant restoration of the visual system through cell-mediated therapeutic mechanisms [21,28-30].

Recently, the Limoli retinal restoration technique (LRRT) has been developed as a potential therapy for currently untreatable retinal disorders. This surgical technique is a variant of Pelaez's intervention, wherein only orbital autologous fat is transplanted in the subscleral space [31-33]. The technique exploits the use of GFs to create an environment conducive to the neuroenhancement of still functioning retina $[34,35]$. The source of autologous GFs in LRRT is an implant of certain cell types of mesenchymal origin, such as adipose stromal cells, adipose tissue-derived stem cells (ADSCs) contained in the stromal vascular fraction of adipose tissue, and platelets (PLTs) obtained from PLT-rich plasma (PRP) prepared from fresh whole blood by centrifugation (Figure 1) [31-35].

The photoreceptors also receive mediated trophic action from potentially improved conditions of Müller cells, retinal pigment epithelium (RPE) cells, and retinal microcirculation.

In order to evaluate the prognosis of treated RP patients, we hypothesized that the larger the residual cell number is, the greater the interaction between the autograft and the membrane receptors of chorioretinal cells, cellular activity, and, ultimately, the improvement of visual performance.

The primary aim of this prospective, pilot clinical study was to evaluate whether autologous stem cell transplantation in patients with RP, via LRRT surgery, may be beneficial to retinal restoration. Furthermore, the secondary aim was to evaluate prognostic factors to identify the time and tests needed to allow appropriate surgical intervention in those affected with RP. 


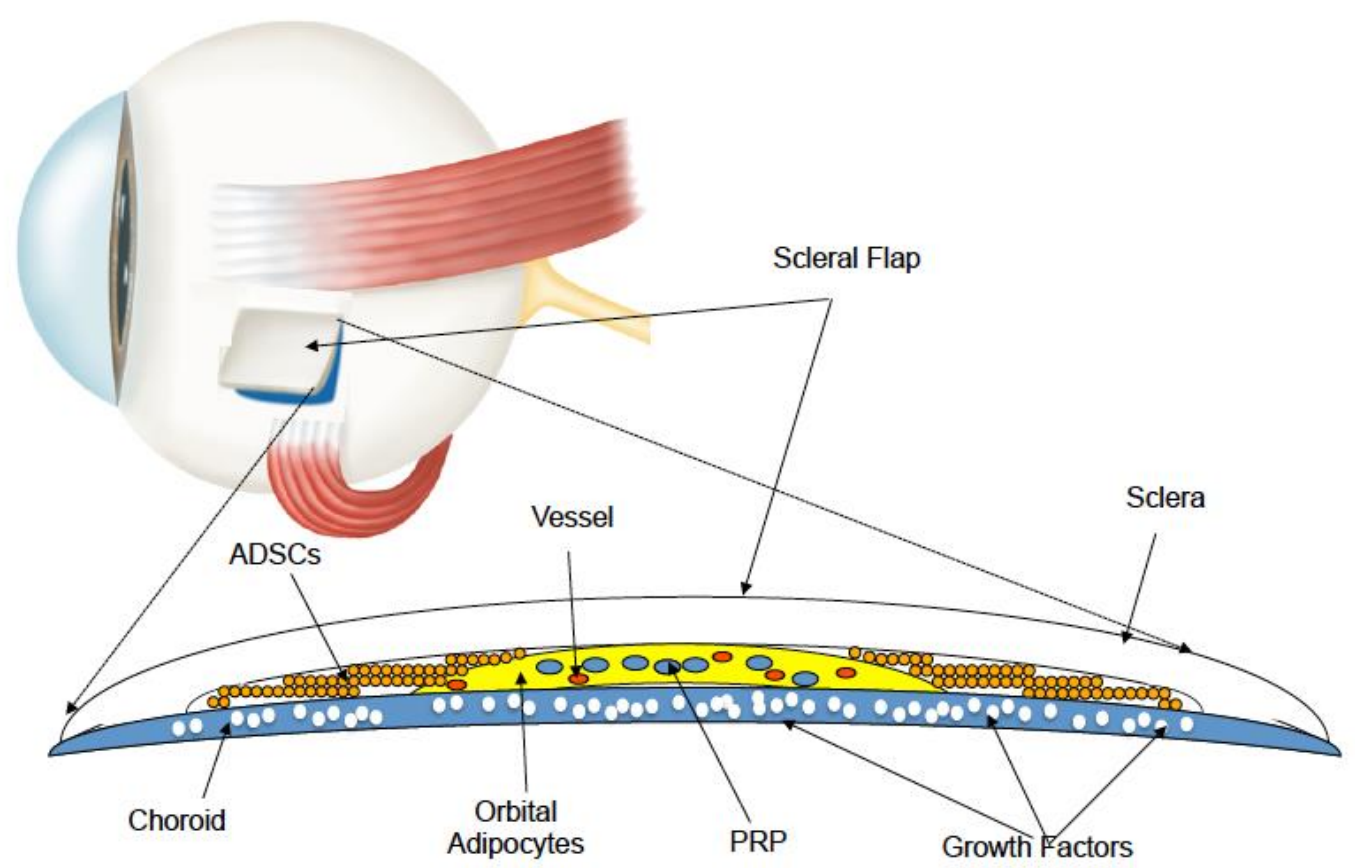

Figure 1. The suprachoroidal autograft obtained by the Limoli retinal restoration technique (LRRT) allows placing adipose stromal cells, adipose tissue-derived stem cells (ADSCs), and platelets (PLTs), obtained from PLT-rich plasma (PRP), close to the choroid. The production of growth factors (GFs), typical of these cells is poured directly into the choroidal flow, helping to maintain retinal cell trophism.

\section{Materials and Methods}

Approval by the Institutional Review Board of the Low Vision Academy (No: 2016/A101, date: 1 October 2016) was obtained, and the study was conducted in accordance with the tenets of the Declaration of Helsinki. All of the patients were individually instructed on the methodology of the study, and written informed consent was obtained from all participants included.

Six patients signed informed consent again to carry out the same intervention in the contralateral eye. In this study, 15 patients with RP were included if they had:

- Clinical diagnosis of RP based on a history of night blindness, visual field constriction, abnormalities on ERG testing, and specific ophthalmoscopic findings;

- $\quad$ Age ranging from 19 to 86 years;

- Normal intraocular pressure;

- Visual acuity for near (close-up) vision between 7 and 64 points (pts) in order to avoid difficult evaluations for both low visus (>64 pts) and normal visus (6 pts);

- Transparent lens;

- Signature of the informed consent;

- Retinitis pigmentosa pattern that can be detected at the macula.

The exclusion criteria were the following:

- Hypermetropy or myopia with spherical equivalent $\geq 6$ diopters;

- Existence of keratoconus, cataract, cystoid macular edema, keratitis, uveitis, etc.;

- Other ocular diseases, for example, glaucoma, optic neuritis, ocular trauma, etc.;

- Lack of patient compliance due to medical conditions, such as Parkinson's disease, diabetes mellitus, hypertension, vasculitis, hypovitaminosis, multiple sclerosis, epilepsy, or other systemic acute or chronic diseases.

A complete ophthalmologic examination was performed, including the measurement of visual acuity for far and near distance: Best corrected visual acuity (BCVA) measured by early treatment 
diabetic retinopathy study (ETDRS) charts at $4 \mathrm{~m}$ in logarithm of the minimum angle of resolution (logMAR) units and close-up visus (pts); slit-lamp biomicroscopy with and without dilatation; applanation tonometry; and fundus examination.

All eyes recruited for the study cohort were divided into two groups. The division was based on foveal thickness (FT) measured with spectral domain OCT (SD-OCT). For this purpose, a cut-off of $\leq 190 \mu \mathrm{m}$ was used. Frequently, in RP patients, the retinal cell population is small, foveal structures are often dystrophic, and the photoreceptor/retinal pigment epithelium/Bruch's membrane/choriocapillaris complex is no longer recognizable. In those patients with thicker FT, the retinal cell population is large, foveal structures are still intact, and the photoreceptor/retinal pigment epithelium/Bruch's membrane/choriocapillaris complex is recognizable. Consequently, the subjects with FT $\leq 190 \mu \mathrm{m}$ were included in group A-FT, whereas subjects with FT $>190 \mu \mathrm{m}$ were included in group B-FT. At baseline (T0) and 6 months after surgery (T180), the ophthalmologic evaluation and the following exams were performed on each patient: SD-OCT, using the Cirrus 5000 (Carl Zeiss Meditec AG, Jena, Germany); microperimetry (MY) by means of Maia 100809 (CenterVue S.p.A., Padua, Italy); ERG test using Retimax (C.S.O. S.r.l., Scandicci, Italy), an ocular electromedical system, in accordance with the 2009 guidelines of the International Society for Clinical Electrophysiology of Vision (ISCEV) [7]. Comprehensive ophthalmic examination and LRRT surgery [31-33] were carried out on all patients by a single retinal specialist (PGL) according to our technique, as detailed in the literature and presented in a video in 2018 [31,33]. Briefly, $10 \mathrm{~mL}$ of fat tissue was harvested manually from the patient's abdominal subcutaneous layer with a cannula connected to a syringe. Pure stromal vascular fraction (SVF) of fat tissue, very rich in ADSCs, was separated from blood, fat, oil, and liquid by centrifugation. Peripheral blood was collected in a Regen-BCT tube (RegenKit; RegenLab, Le Mont-sur-Lausanne, Switzerland) for PRP gel preparation and was centrifuged for $5 \mathrm{~min}$.

A suprachoroidal pocket was created in the patient's eye to place the cell graft and was filled with a precise amount of ADSCs and SVF. A 5-mm-deep scleral door was opened by radial hinge in the infero-temporal quadrant at $8 \mathrm{~mm}$ from the limbus. Orbital fat was collected from the space above the inferior oblique muscle. The adipose flap obtained was placed gently on the bed and sutured with choroidal vicryl 6/0 at the proximal edge of the door. Subsequently, $1 \mathrm{cc}$ of PRP was injected in the stroma of the peduncle using a 25-gauge cannula. As a result, an autograft composed of fat cells, ADSCs from SVF, and PRP was carried out.

\section{Statistical Analysis}

Data are presented as mean \pm standard deviation (SD); minimum and maximum (min-max) values are reported as well. Mixed regression models with robust errors were applied to analyze the difference between the two groups according to the foveal thickness by SD-OCT with A-FT $\leq 190 \mu \mathrm{m}$ and B-FT $>190 \mu \mathrm{m}$ at the two moments (baseline $=\mathrm{T} 0$, and after 6 months $=\mathrm{T} 180$ ) considering that two eyes could be observed for one patient (patient as random effect). Also, the effect of the interaction between the group and time was evaluated.

A $p$-value $<0.05$ was considered statistically significant. All statistical analyses were done with STATA v14 (Collage Station, Texas, USA).

\section{Results}

A total of 21 eyes of 15 patients affected with RP, 9 males and 6 females (mean age $52.06 \pm 19.31$ years, range 19-86 years) were enrolled in the study (Table 1). The visual functional and anatomical parameters and the average values recorded at baseline (T0) and at 6 months (T180) after surgery are shown in Table 2. 
Table 1. Demographic data of retinitis pigmentosa (RP) patients with foveal thickness (FT) $\leq 190 \mu \mathrm{m}$ (A-FT) and $>190 \mu \mathrm{m}(\mathrm{B}-\mathrm{FT})$.

\begin{tabular}{cccc}
\hline Patients & Group A-FT $\leq \mathbf{1 9 0} \boldsymbol{\mu \mathbf { m }}$ & Group B-FT $>\mathbf{1 9 0} \boldsymbol{\mu \mathbf { m }}$ & Total \\
\hline Number: Patients/eyes & $6 / 8$ & $9 / 13$ & $15 / 21$ \\
Age years ( \pm standard & $40.33(13.98)$ & $59.88(18.93)$ & $52.06(19.31)$ \\
deviation (SD)) & $19-54$ & $32-86$ & $21-82$ \\
Range (years) & $3 / 3$ & $3 / 6$ & $6 / 9$ \\
Female/male & $2 / 6$ & $7 / 6$ & $9 / 12$ \\
Eye: Right/left & & & \\
\hline
\end{tabular}

Table 2. Descriptive characteristics of analyzed parameters in the two groups according to the foveal thickness (FT): A-FT $\leq 190 \mu \mathrm{m}(n=8)$ and B-FT $>190 \mu \mathrm{m}(n=13)$, at baseline (T0) and at 6 months (T180); mixed model results.

\begin{tabular}{|c|c|c|c|c|c|c|c|}
\hline Parameters & Group & $\begin{array}{c}\text { Mean } \pm \text { SD } \\
\text { Min-Max }\end{array}$ & Values (T0) & Values (T180) & $\%$ & $\begin{array}{c}\text { Time Effect } \\
p \text {-Value }\end{array}$ & $\begin{array}{c}\text { Group Effect } \\
p \text {-Value }\end{array}$ \\
\hline \multirow{4}{*}{$\log M A R$} & \multirow{2}{*}{ A-FT $\leq 190 \mu \mathrm{m}$} & mean $\pm S D$ & $1.02 \pm 0.76$ & $1.01 \pm 0.77$ & +1.76 & & \\
\hline & & $\min -\max$ & $0.10-2.70$ & $0.10-2.70$ & & & \\
\hline & \multirow{2}{*}{ B-FT >190 $\mu \mathrm{m}$} & mean $\pm S D$ & $0.47 \pm 0.21$ & $0.45 \pm 0.18$ & +4.51 & & \\
\hline & & $\min -\max$ & $0.15-0.70$ & $0.15-0.79$ & & 0.562 & 0.051 \\
\hline \multirow{3}{*}{ pts } & \multirow{2}{*}{ A-FT $\leq 190 \mu \mathrm{m}$} & mean $\pm \mathrm{SD}$ & $25.88 \pm 20.29$ & $26.13 \pm 21.03$ & & & \\
\hline & & $\begin{array}{c}\min -\max \\
\operatorname{mean} \pm S D\end{array}$ & $\begin{array}{c}8-64 \\
15.15 \pm 5.86\end{array}$ & $\begin{array}{c}7-64 \\
12 \pm 4\end{array}$ & +20.79 & & \\
\hline & B-FT $>190 \mu \mathrm{m}$ & $\min -\max$ & $\begin{array}{c}10.15 \pm 3.06 \\
7-26\end{array}$ & $7-18$ & +20.79 & 0.269 & 0.08 \\
\hline \multirow{4}{*}{ dB MAIA } & \multirow{2}{*}{ A-FT $\leq 190 \mu \mathrm{m}$} & mean \pm SD & $5.45 \pm 6.8$ & $6.29 \pm 8.11$ & +15.41 & & \\
\hline & & $\min -\max$ & 0-16 & 0-18.2 & & & \\
\hline & \multirow{2}{*}{ B-FT >190 $\mu \mathrm{m}$} & mean $\pm \mathrm{SD}$ & $3.15 \pm 6.45$ & $4.18 \pm 7.79$ & +32.70 & & \\
\hline & & $\min -\max$ & 0-19.4 & 0-21.8 & & 0.003 & 0.535 \\
\hline \multirow{3}{*}{$\mathrm{C} \mu \mathrm{m}$} & $\mathrm{A}-\mathrm{FT} \leq 190 \mu \mathrm{m}$ & $\begin{array}{c}\operatorname{mean} \pm S D \\
\min -\max \end{array}$ & $\begin{array}{c}140.75 \pm 37.42 \\
49-160\end{array}$ & $\begin{array}{c}133.88 \pm 54.28 \\
0-161\end{array}$ & -0.05 & & \\
\hline & \multirow{2}{*}{ B-FT >190 $\mu \mathrm{m}$} & mean \pm SD & $275.46 \pm 88.1$ & $275.08 \pm 89$ & 0.00 & & \\
\hline & & $\min -\max$ & 195-462 & 187-471 & & 0.303 & $<0.001$ \\
\hline \multirow{3}{*}{$\mu \mathrm{m}^{3}$} & A-FT $\leq 190 \mu \mathrm{m}$ & $\begin{array}{c}\operatorname{mean} \pm S D \\
\min -\max \end{array}$ & $\begin{array}{c}7.03 \pm 1.39 \\
4.6-8.7\end{array}$ & $\begin{array}{c}7.67 \pm 0.45 \\
7.3-8.6\end{array}$ & +0.09 & & \\
\hline & \multirow{2}{*}{ B-FT >190 $\mu \mathrm{m}$} & mean $\pm S D$ & $8.92 \pm 1.38$ & $8.79 \pm 1.48$ & -0.01 & & \\
\hline & & $\min -\max$ & $6.5-10.7$ & $6.5-11$ & & 0.806 & 0.023 \\
\hline \multirow{3}{*}{$\mathrm{A} \mu \mathrm{m}^{2}$} & A-FT $\leq 190 \mu \mathrm{m}$ & $\begin{array}{c}\operatorname{mean} \pm \mathrm{SD} \\
\min -\max \end{array}$ & $\begin{array}{c}202.49 \pm 23.4 \\
164.9-240\end{array}$ & $\begin{array}{c}212.86 \pm 12.75 \\
202-239\end{array}$ & +0.05 & & \\
\hline & \multirow{2}{*}{ B-FT >190 $\mu \mathrm{m}$} & mean $\pm S D$ & $247.62 \pm 38.69$ & $244.15 \pm 40.4$ & -0.01 & & \\
\hline & & $\min -\max$ & 179-299 & 181-305 & & 0.949 & 0.023 \\
\hline
\end{tabular}

LogMAR: Logarithm of the minimum angle of resolution; pts: Close-up visus in points; dB MAIA: Microperimetric sensitivity in deciBel. C $\mu \mathrm{m}$ : Thickness of central fovea (in $\mu \mathrm{m}) ; \mu \mathrm{m}^{3}$ : Volume area; $\mathrm{A}^{2} \mathrm{~m}^{2}$ : Average of retinal thickness (in $\mu \mathrm{m}$ ); SD: Standard deviation.

Based on FT, 8 of the 21 eyes were classified in group A (FT $\leq 190 \mu \mathrm{m})$ and the remaining 13 were classified in group B (FT $>190 \mu \mathrm{m})$. All 15 patients completed the 6-month follow-up and none had systemic complications intra-operatively and post-operatively throughout that period. Mean values of the intraocular pressure recorded before and after surgery did not change significantly. The mixed model results showed a significant difference between the two groups in close-up visus. Specifically, group A-FT showed mean higher values than the group with $>190 \mu \mathrm{m}$ (group effect $p=0.031$ ). While group B-FT showed significantly higher mean values than group A-FT in central fovea thickness $(\mathrm{C} \mu \mathrm{m}), \mu \mathrm{m}^{3}$, and average retinal thickness $\left(\mathrm{A} \mu \mathrm{m}^{2}\right)$ (Table 2). In all models, the interaction Time/Group had no significant effect (Table 3). 
Table 3. Variation between time at baseline (T0) and at 6 months (T180) estimated by mixed model in two groups according to the foveal thickness (FT): A-FT $\leq 190 \mu \mathrm{m}$ (8 eyes) and B-FT $>190 \mu \mathrm{m}$ (13 eyes).

\begin{tabular}{ccccc}
\hline \multicolumn{2}{c}{ Variation (T180-T0) } & $\begin{array}{c}\text { A-FT } \leq \mathbf{1 9 0} \boldsymbol{\mu m} \\
\mathbf{8} \text { Eyes }\end{array}$ & $\begin{array}{c}\text { B-FT }>\mathbf{1 9 0} \boldsymbol{\mu m} \\
\text { 13 Eyes }\end{array}$ & $\begin{array}{c}\text { Interaction Effect } \\
\boldsymbol{p} \text {-Value }\end{array}$ \\
\hline logMAR & mean \pm SD & $-0.02 \pm 0.07$ & $-0.02 \pm 0.04$ & 0.971 \\
pts & mean \pm SD & $0.25 \pm 3.76$ & $-3.15 \pm 1.24$ & 0.390 \\
dB MAIA & mean \pm SD & $0.84 \pm 0.59$ & $1.02 \pm 0.53$ & 0.818 \\
C $\mu \mathrm{m}$ & mean \pm SD & $-6.88 \pm 6.71$ & $-0.38 \pm 1.59$ & 0.346 \\
$\mu \mathrm{m}^{3}$ & mean \pm SD & $0.35 \pm 0.37$ & $-0.12 \pm 0.18$ & 0.248 \\
$\mathrm{Am}^{2}$ & mean $\pm \mathrm{SD}$ & $5.66 \pm 5.63$ & $-3.46 \pm 4.66$ & 0.212 \\
\hline
\end{tabular}

LogMAR: Logarithm of the minimum angle of resolution; pts: Close-up visus in points; dB MAIA: Microperimetric sensitivity in deciBel; $C \mu \mathrm{m}$ : Thickness of central fovea (in $\mu \mathrm{m}) ; \mu \mathrm{m}^{3}$ : Volume area; $\mu^{2} \mathrm{~m}^{2}$ : Average of retinal thickness (in $\mu \mathrm{m}$ ); SD: Standard deviation.

The ophthalmologic evaluation included the measurement of visual acuity for far and near distance: BCVA measured by ETDRS charts at $4 \mathrm{~m}$ in $\log M A R$ units. Mean BCVA before the treatment was $1.02 \pm 0.76 \log$ MAR $(20 / 200)$ in group A-FT $(n=8)$ and $0.47 \pm 0.21 \log$ MAR $(20 / 200)$ in group B-FT $(n=13)$. Specifically, BCVA in group A-FT varied from 1.02 to $1.01 \operatorname{logMAR}(+1.76 \%)$, and from 0.47 to $0.45 \log$ MAR $(+4.51 \%)$ in group B-FT (Figure 2$)$.

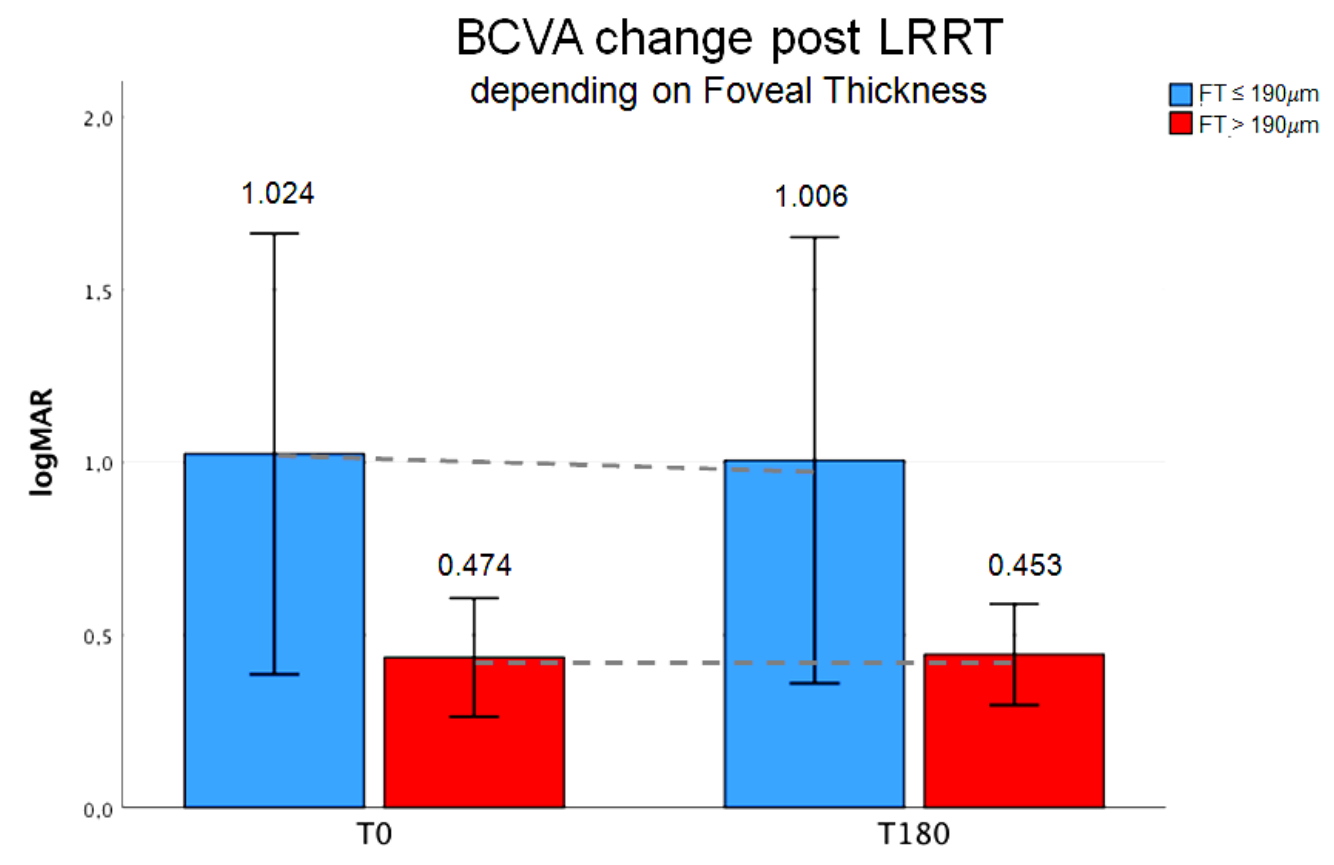

Figure 2. The best corrected visual acuity (BCVA), in logarithm of the minimum angle of resolution (logMAR) units, was stable after suprachoroidal autograft or increased $(+4.51 \%)$ in patients with foveal thickness (FT) >190 $\mu \mathrm{m}$ (13 eyes) (B-FT group, green bars). LRRT: Limoli retinal restoration technique; T0: Baseline; T180: At 6 months from surgery. A-FT group with FT $\leq 190 \mu \mathrm{m}$ (8 eyes, blue bars).

No patient showed a reduction in BCVA at the 6-month follow-up. There was no statistically significant difference in visual acuity from baseline within the same group or between the two groups at 6 months ( $1.01 \pm 0.77$ vs. $0.45 \pm 0.18$, respectively). Percentage variation was lower in $\mathrm{A}(-1.76 \%)$ than in B $(-4.43 \%)$.

Close-up visus in points (pts): At baseline, mean close-up visus was $25.88 \pm 20.29$ pts in group A-FT (8 eyes), and $15.15 \pm 5.86$ pts in group B-FT (13 eyes). 
At the 6-month follow-up visit, it decreased to 26.13 pts in group A, whereas it increased to $12.00 \mathrm{pts}$ in group $\mathrm{B}$, showing that there was a trend towards significance in the latter group. Percentage variation was negative in A $(-0.97 \%)$; conversely, it was greatly increased in B $(+20.79 \%)$ (Figure 3$)$.

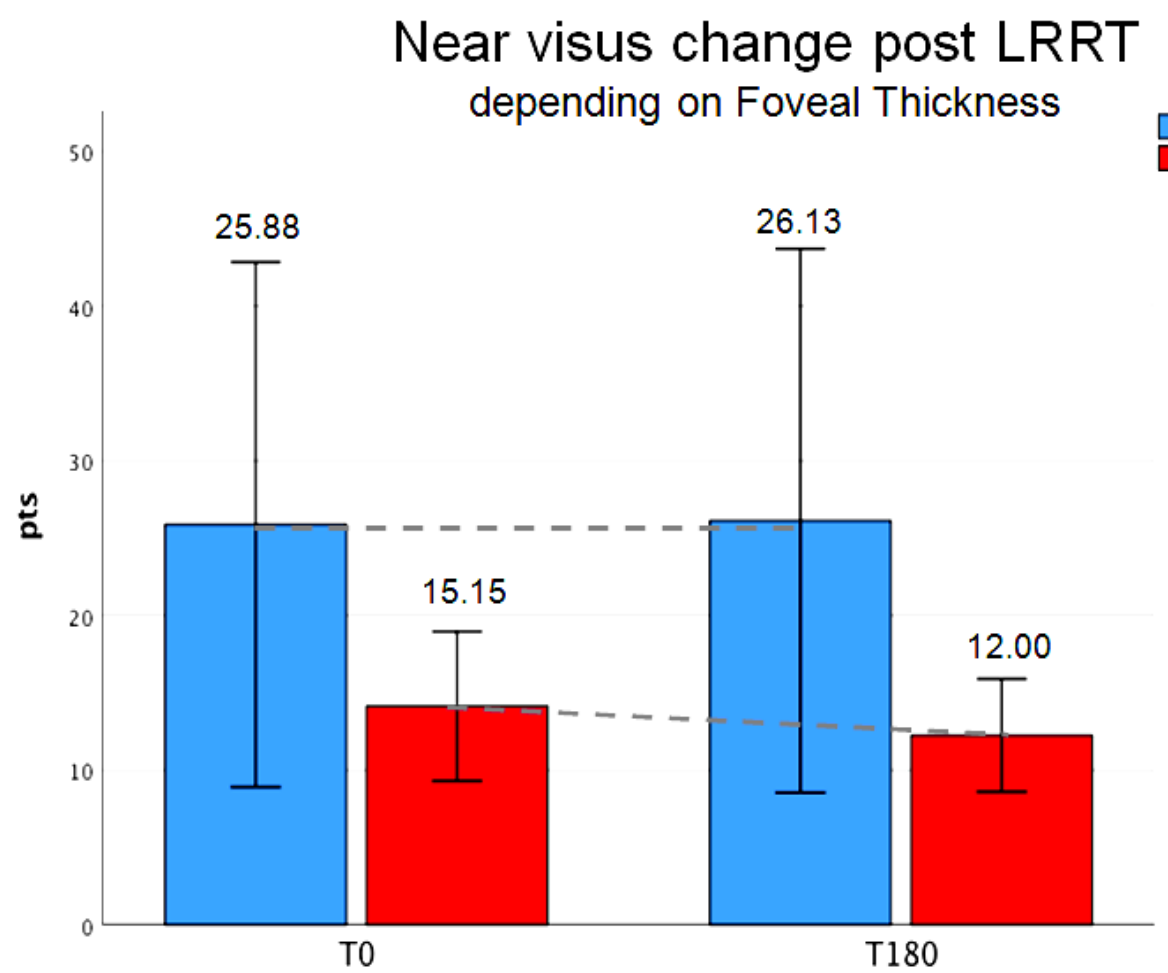

Figure 3. Close-up visus, in points (pts), change post-Limoli retinal restoration technique (LRRT) depending on foveal thickness (FT). Six months after surgery (T180) from the baseline (T0), close-up visus was stable in group A-FT (FT $\leq 190 \mu \mathrm{m}$, blue bars) and increased in group B-FT (FT > $190 \mu \mathrm{m}$, green bars). The increase was $+20.79 \%$, corresponding to useful reading area (6-10 pts: Book, journal, etc.). Average at T0 was $25.88( \pm 20.28 \mathrm{SD})$ and at T180 was $26.13( \pm 21.03 \mathrm{SD})$ in group A-FT. Average at T0 was $15.15( \pm 5.85 \mathrm{SD})$ and at T180 was $12.00( \pm 4.00 \mathrm{SD})$ in group B-FT.

The average threshold sensitivity by MY at baseline was $5.45 \pm 6.79 \mathrm{~dB}$ in group A-FT $(n=8)$, and $3.15 \mathrm{~dB} \pm 6.45 \mathrm{SD}$ in group B-FT ( $n=13)$. In the 6-month follow-up, it increased in both groups (6.29 $\mathrm{dB} \pm 8.11 \mathrm{SD}$ vs. $4.18 \mathrm{~dB} \pm 7.79 \mathrm{SD}$, respectively).

Percentage improvement in retinal sensitivity was lower in group A $(+15.41 \%)$ than in group B (+32.70). Despite the improvement in retinal sensitivity, it was not significant within the same group or between the two groups (Figures 4-6). 


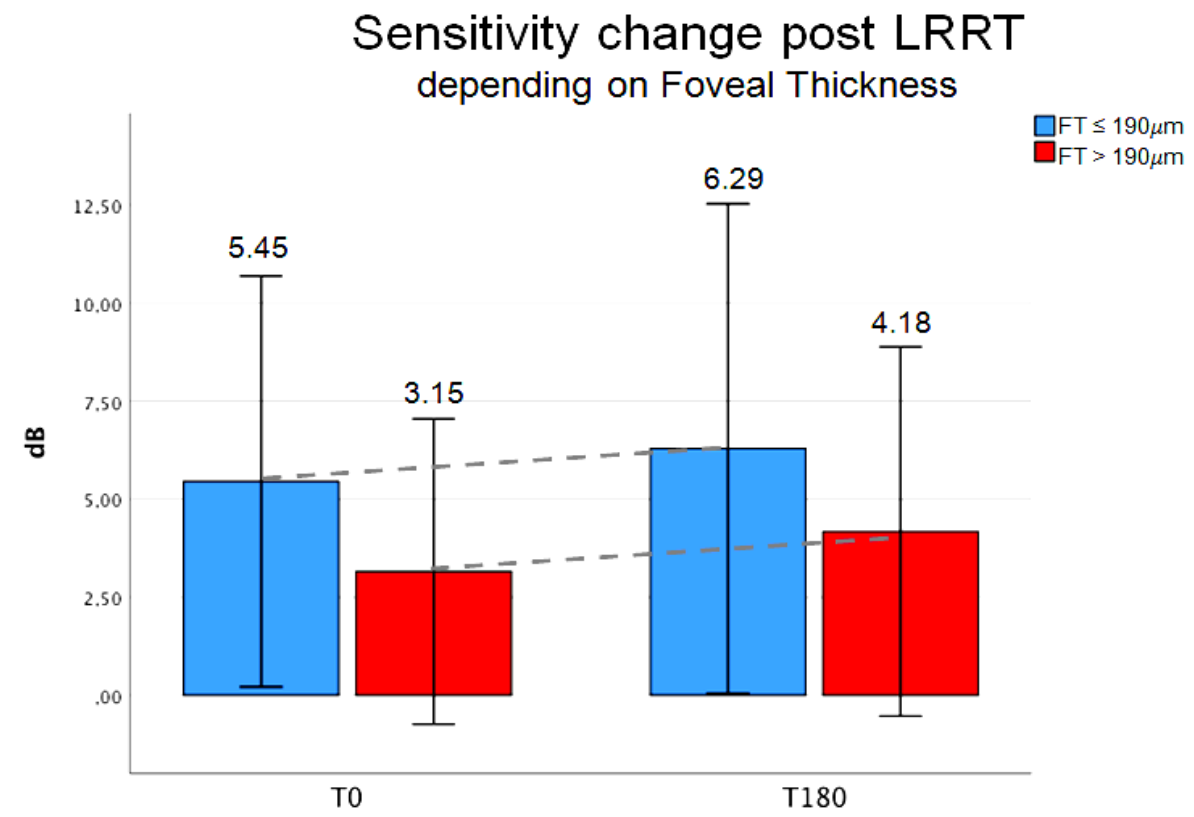

Figure 4. At 6 months (T180) from Limoli retinal restoration technique (LRRT), there was a more relevant to, $+32.70 \%$, for sensitivity in the group with foveal thickness (FT) $>190 \mu \mathrm{m}$ (B-FT, green bars). Sensitivity in group A-FT (blue bars) was $+15.41 \%$. Average at T0 was 5.45 ( $\pm 6.79 \mathrm{SD}$ ) and at T180 was 6.29 ( $\pm 8.10 \mathrm{SD})$ in group A-FT. Average at T0 was $3.15( \pm 6.44 \mathrm{SD})$ and at T180 was $4.18( \pm 7.78 \mathrm{SD})$ in group B-FT.
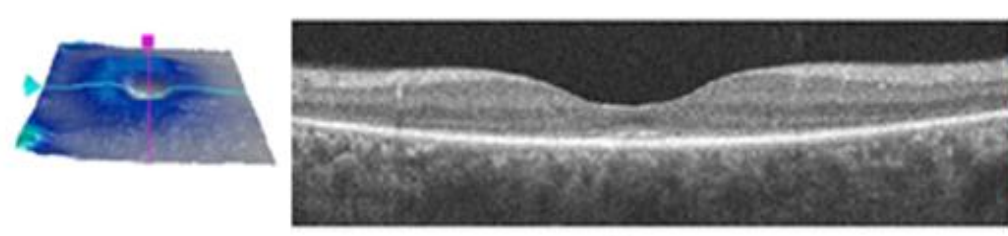

A

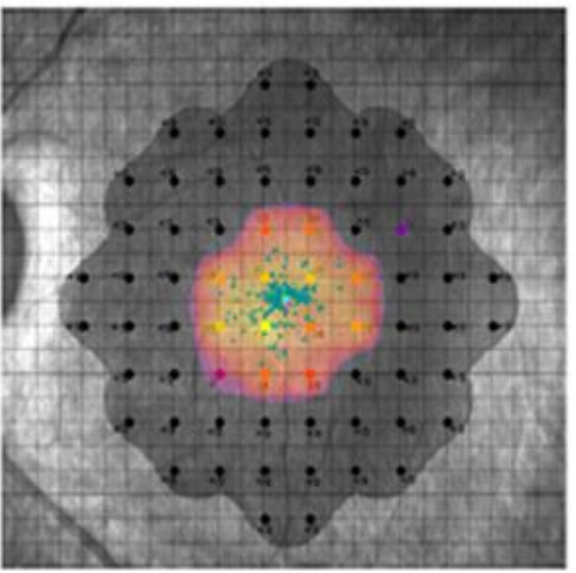

B

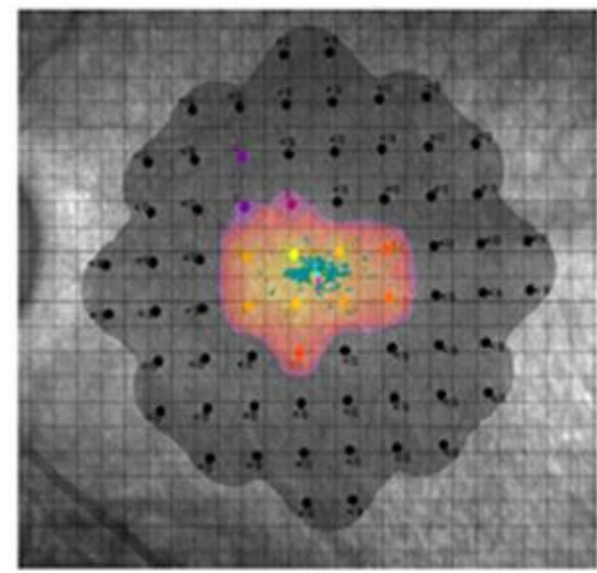

C

Figure 5. Retinitis pigmentosa (RP) patient with thinner foveal thickness (FT) $<190 \mu \mathrm{m}$ (group A-FT). (A) The retinal cell population is small, foveal structures are often dystrophic, and the photoreceptor/retinal pigment epithelium/Bruch's membrane/choriocapillaris complex is no longer recognizable. (B,C) The microperimetric sensitivity after surgery changed from 2 to $1.4 \mathrm{~dB}$, and best corrected visual acuity (BCVA) changed from 0.097 to 0.155 logarithm of the minimum angle of resolution (logMAR). 

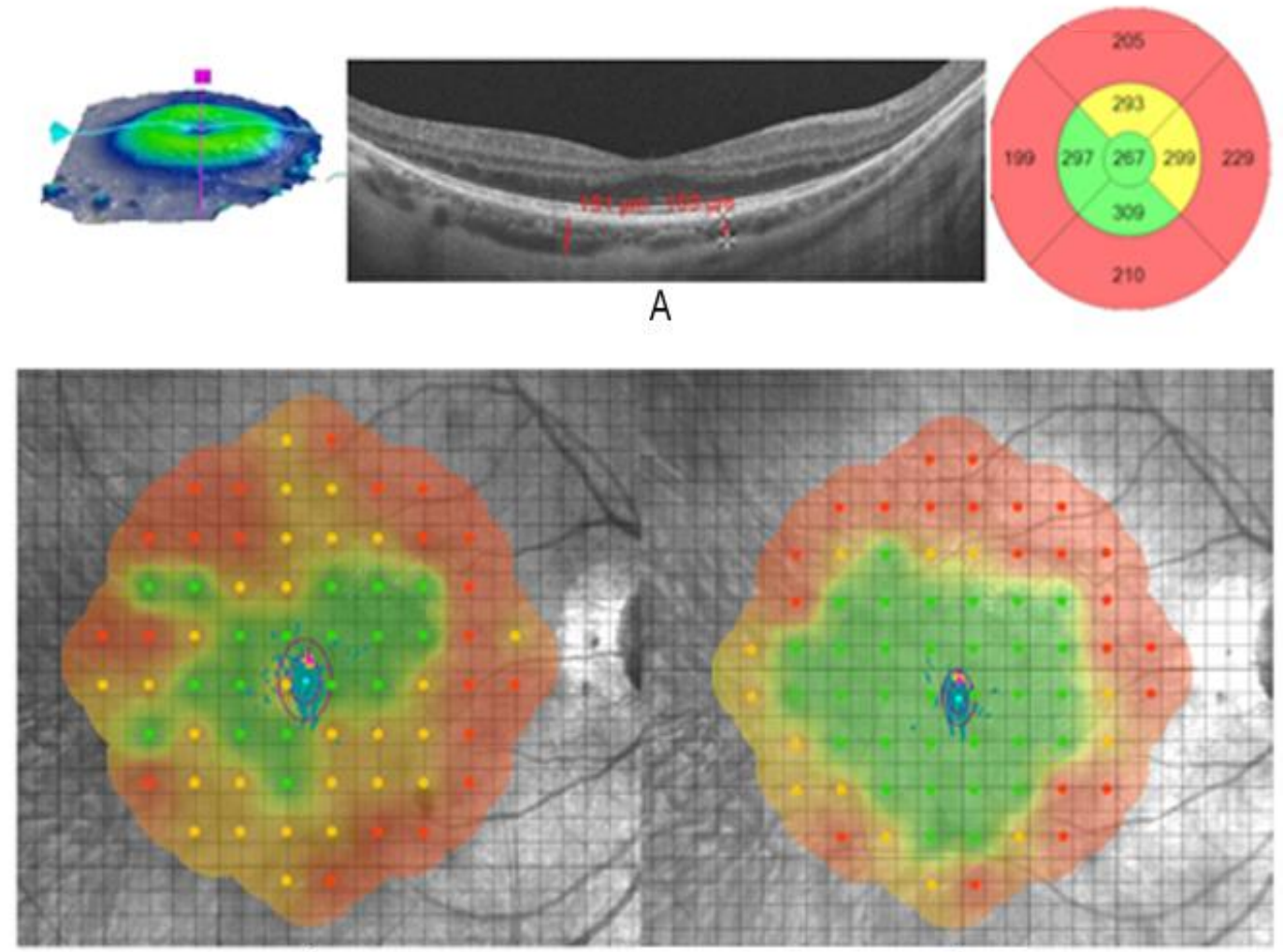

B

C

Figure 6. Retinitis pigmentosa (RP) patient with foveal thickness (FT) $>190 \mu \mathrm{m}$ (group B-FT). (A) The retinal cell population is large, foveal structures are still intact, and the photoreceptor/retinal pigment epithelium/Bruch's membrane/choriocapillaris complex is recognizable. (B,C) The microperimetric sensitivity after surgery changed from 14.41 to $16.61 \mathrm{~dB}$ and bivariate contour ellipse area (BCEA) (see central oval circles), used for fixation stability evaluation, changed from 2.0 to 0.9 using microperimetry (MY) device. Best corrected visual acuity (BCVA) changed from 0.045 to 0.000 logmar of the minimum angle of resolution (logMAR).

Surveying the subjective experience of all patients at 6 months post-surgery with patient compliance analysis, it was reported that visual performances improved in 15 out of 21 eyes $(71.43 \%)$, were unchanged in 4 eyes (19.05\%), and worse in 2 eyes (9.52\%) (Table 4$)$.

Table 4. Compliance analysis at 6 months (T180) post-surgery in two groups according to the foveal thickness (FT): A-FT $\leq 190 \mu \mathrm{m}$, and B-FT $>190 \mu \mathrm{m}$.

\begin{tabular}{ccccc}
\hline Compliance & A-FT $\leq \mathbf{1 9 0} \boldsymbol{\mu m} \mathbf{( 8}$ Eyes) & \multicolumn{1}{c}{ B-FT $>\mathbf{1 9 0} \boldsymbol{\mu m} \mathbf{( 1 3}$ Eyes) } \\
\hline Improved & 4 & $50.00 \%$ & 11 & $84.62 \%$ \\
Unchanged & 3 & $37.50 \%$ & 1 & $7.69 \%$ \\
Worse & 1 & $12.50 \%$ & 1 & $7.69 \%$ \\
\hline
\end{tabular}

However, examining patient feedback according to foveal thickness, the perception of improvement would be greater for patients with FT $>190 \mu \mathrm{m}$ (11 eyes, 84.62\%), rather than for patients with $\mathrm{FT} \leq 190 \mu \mathrm{m}$ (4 eyes, 50\%) (Figure 7). If we considered the improved group alone, 11 eyes $(73.33 \%)$ belonged to group B, and 4 (26.67\%) to group A (Figure 7). 


\section{Subjective Feedback 6 months after LRRT}

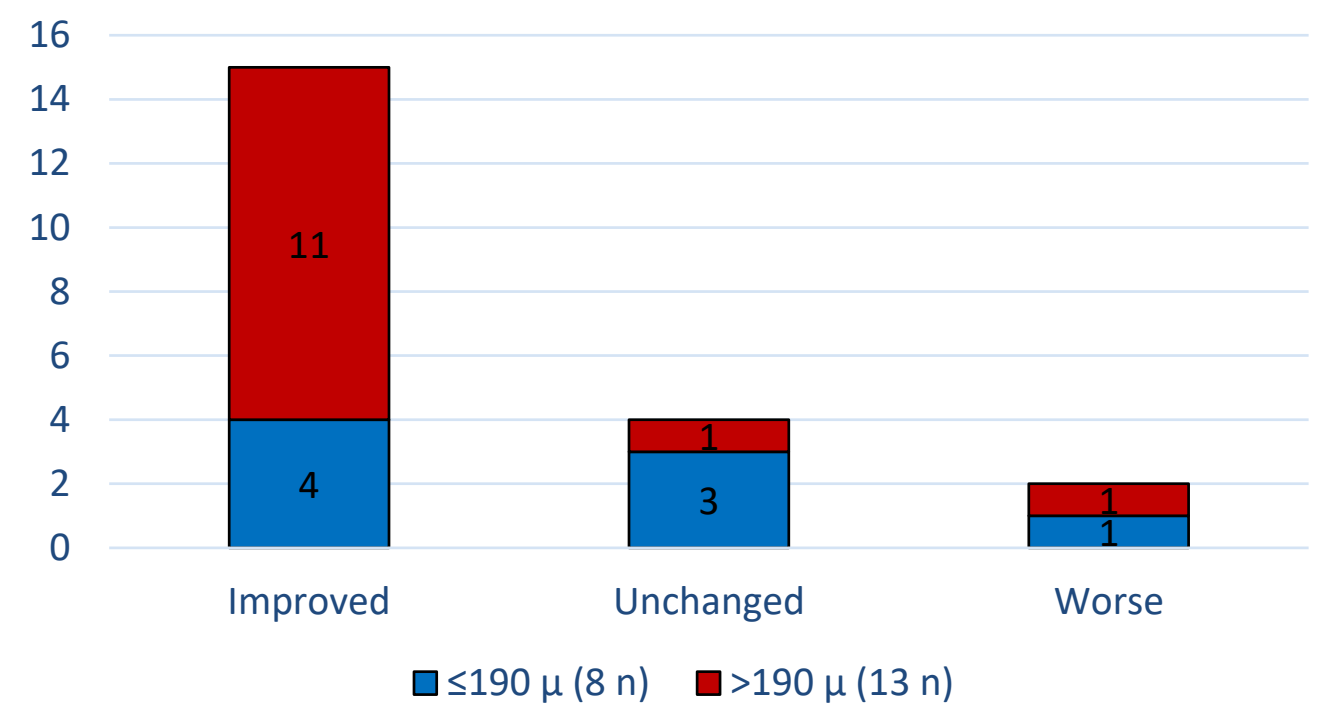

Figure 7. Retinitis pigmentosa (RP) patient compliance analysis at 6 months post-surgery depending on foveal thickness (FT). Compliance was good in $71.43 \%$ of all cases (groups A-FT and B-FT). Patients reported seeing better, but the percentage reached $84.62 \%$ in those with FT $>190 \mu \mathrm{m}$. In the improved group, 11 eyes (73.33\%) belonged to group B-FT (green bars), and 4 (26.67\%) to group A-FT (blue bars).

\section{Discussion}

The main objectives of our suprachoroidal autograft technique were to evaluate whether autologous stem cell transplantation may be useful for retinal restoration through the paracrine secretion of factors promoting vascular pedicle fat engraftment with the underlying tissue, and by enhancing pedicle fat original vascularization to ensure its volume and survival. Furthermore, the secondary aim was to evaluate prognostic factors to identify the time and tests needed to allow appropriate surgical intervention in those affected with RP.

LRRT cell therapy has been proven to have an impact on certain functional parameters after interaction with the residual cells. Close-up visus and retinal sensitivity improved in group B-FT, in which foveal thickness was greater, compared to group A-FT, with thinner FT and lower cellularity. Results of our study cast light on the therapeutic potential of stem cell implant activity that therefore could be crucial for retinal degeneration. Given these findings, the group with a foveal thickness greater than 190 microns was associated with a better prognosis, while in patients with thinner FT, the low cellular concentration might hinder the alleged beneficial interactions between stem cell implants and membrane receptors. Hence, central thickness is an important parameter to understand the complex processes underlying RP progression.

The myriad of bioactive factors released by the graft of three different types of autologous cells could be as follows:

(1) Fat cells, which are contained in the pedicle grafted into the suprachoroidal space, secrete basic fibroblast GF (bFGF), interleukin (IL), epidermal GF (EGF), transforming GF (TGF), pigment epithelium-derived factor (PEDF), insulin-like GF-1 (IGF-1), and adiponectin [36-38].

(2) ADSCs secrete bFGF, vascular endothelial GF (VEGF), granulocyte-macrophage colony-stimulating factor (GM-CSF), macrophage colony-stimulating factor (M-CSF), TGF, hepatocyte GF, IGF-1, IL, angiogenin, placental GF (PIGF), ciliary neurotrophic factor (CNTF), and brain-derived neurotrophic factor (BDNF) [39,40]. 
PLTs secrete platelet-derived GF (PDGF), VEGF, bFGF, TGF, EGF, IGF-1, platelet-derived angiogenesis factor (PDAF), and thrombospondin (TSP) [41,42]. Hence, the rationale behind this autograft lies in exploiting the stabilizing effect exerted by cytokines and GFs released by the grafted cells. Direct contact of the autograft with the choroid enhances the incretion of these bioactive actors into the choroidal flow, and consequently favors their dissemination throughout the retinal tissue and in the vitreous body.

GF binding to its own specific receptor in the target cell is the initial step that triggers an intracellular signaling transduction cascade, activating second messengers. The latter can activate specific intracellular biochemical pathways generally by a series of phosphorylation events, with the ultimate aim of regulating enzyme activity or gene expression [43,44].

Notably, the activated transcription factors, entering the nucleus and binding directly or indirectly to DNA, could regulate the expression of various genes with different mechanisms, promoting an increased synthesis of proteins, including enzymes and cytokines [32].

The significance of stem cell implants lies in their essential role of cell cycle regulation, since their presence could trigger the cell transition from $G_{0}$ or quiescent phase to $G_{1}$ or growth phase, which is necessary to enter the cellular growth cycle. Moreover, they are also important for stimulating a wide range of cellular processes, including mitosis, cell survival, migration, and cellular differentiation [45].

Mesenchymal cell graft into the sovrachoroidal space should promote a continuous incretion of GFs that are capable of interfering with the evolution of RP in several ways: Antioxidant, antinflammatory, antiapoptotic, citoprotective, and hemorheological activities [46,47].

Antioxidant activity. The bFGF and BDNF concentration within the photoreceptors has been shown to increase in response to stress in order to promote retinal cell survival and to prevent oxygen-induced photoreceptor cell death in the posterior retina. [48-52]. Moreover, rod survival is essential for extending the life span of cones inasmuch as the paracrine secretion of rod-cone viability factor (RdCVF) by rods is a pivotal trophic factor for cone survival $[53,54]$. It has been demonstrated that RdCVF has an antioxidant activity, and decreases cone death in $\mathrm{rd} 10$ and $\mathrm{P} 23 \mathrm{H}$ transgenic rat models [55].

Antinflammatory activity. Several studies have reported that the activation of microglia generally occurs simultaneously or just before the peak of apoptotic photoreceptor death in RP [56,57]. The eye is an immune-privileged organ, and microglia and RPE cells are the front line of retinal immune defense [58]. Not only does RPE perform a number of processes essential for retinal homeostasis and function, but RPE cells are capable of secreting a diversified panel of proinflammatory cytokines, e.g., IL-6, IL-8, monocyte chemoattractant protein-1, and interferon- $\beta$ (IFN- $\beta$ ), as well as anti-inflammatory factors, such as IL-11 and TGF- $\beta$ [59-61]. Furthermore, microglial cells normally exist in a quiescent state until they are activated by the debris of dead or apoptic cells, lipopolysaccharides, or reactive oxygen species (ROS) during the course of RP [62,63]; they express a unique set of proinflammatory cytokines and chemokines $[64,65]$. In addition, intravitreal administration of MSC has been shown to have a remarkable effect on the host immune response by suppressing proinflammatory cytokine production, such as IFN- $\beta$ and tumor necrosis factor- $\alpha$ through IL-1 receptor antagonist, and prostagandin E2 receptor activation [37]. Another study by Guadagni et al. has shown that a microenvironment supplemented with GFs can slow down the genetically determined photoreceptor death, concurrently reducing retinal inflammation, and thereby establishing framework conditions for the viability of the overall cell population [17].

Antiapoptotic activity. Excess generation of ROS causes damage to membrane lipoproteins and cellular DNA, thus leading to apoptosis and photoreceptor death [66-69]. The GFs excreted by grafted mesenchymal cells can facilitate $\mathrm{Bcl}-2$ gene expression in order to avoid the unrelenting cell death [21]. Bcl-2 family proteins are most notable for their regulation of apoptosis by interacting with caspases [70-75]. More specifically, the process is orchestrated by regulatory cytokines by either inhibiting or inducing apoptosis by blocking inhibitory mediators [75,76]. The latter process could be avoided, or at least delayed, by the anti-apoptotic activation of the $B c l-2$ gene induced by GFs 
derived from implanted mesenchymal cells. Basically, these factors replace those that should have been produced by retinal cells, which are quantitatively reduced and functionally impaired due to RP $[66,68,71]$.

Citoprotective activity. In rat models with inherited retinal dystrophy, it has been shown that MSC contributes to visual function by the putative paracrine release of trophic cytokines that promote the clearance of dysmetabolic products of photoreceptors by RPE phagocytes [35]. Data from another similar study provide evidence that neurotrophic factors, i.e., bFGF, PEDF, nerve GF released by adipose tissue-derived MSCs, are involved in ensuring the survival of both retinal ganglion cells and photoreceptors $[77,78]$. In addition, VEGF released by PRP has been shown to stimulate the proliferation of ADSCs that hence promote the survival of grafted autologous fat and adipocytes [79].

Hemorheological activity. The progressive photoreceptor loss that occurs in RP has been identified as the cause of microvascular dysfunction due to the release of cellular waste products secondary to apoptosis. In this case, as well, the ensuing altered perfusion may end up in a vicious circle, leading to the final loss of photoreceptors [80]. Decreased choroidal blood flow is now known to induce dysfunction of visual sensitivity [81]. Research publications across different study settings support that blood flow is decreased in RP. By proper monitoring of intraocular pressure, Langham and Kramer highlighted the association between choroidal ischemia and visual loss, as well as RPE cell degeneration in RP patients [82]. Beutelspacher et al. found that retinal blood flow is lower in RP patients than the control group, thus concluding that the ensuing reduction of retinal vessels is a typical feature of RP [83]. Turksever et al. demonstrated that retinal oxygen uptake in RP patients is decreased, having found increased venous oxygen saturation in the case group [84]. Ayton et al. and Murakami et al. showed that RP patients had a thinner choroid than the control group, and observed that those patients were characterized by reduced visual acuity, thereby assuming that the choroidal thickness in RP can be a potential predictor of the therapeutic outcome $[85,86]$. Several factors, such as VEGF, bFGF, angiogenin, PDAF, PIGF, PDGF, EGF, and TGF- $\beta$, have been shown to promote endothelial regeneration and may therefore contribute to reperfusion of the choriocapillaris [87-89]. PLTs, primarily known for their contribution to hemostatis, are also able to release factors that promote tissue repair and regeneration and angiogenesis [5,41]. PRP acts as a trigger for the early development of a new capillary plexus, facilitating oxygen and nutrient diffusion towards the grafted cells $[87,88,90]$.

Our research presents limits and critical points that will have to be addressed later to clarify some concepts and deepen the study on patients treated with the exposed technique. The following will be needed:

(1) A greater number of patients and operated eyes with homogeneous age range;

(2) Longitudinal studies to evaluate the longevity of the grafted tissue;

(3) Biomolecular studies to understand the paracrine increment of the autograft;

(4) Genetic tests obtained from patients to allow differentiation in homogeneous research groups, as genetic diagnosis will surely become more relevant in coming years, and it will be possible to determine the impact of MSC administration on different genetic groups of RP patients;

(5) Evaluation of the suitable time in which the autograft must be performed in order to avoid failure in the presence of markedly degenerated retinal tissue. In particular, the results of this study show that FT might be considered a prognostic criterion for RP patients undergoing treatment by LRRT.

\section{Conclusions}

In light of the above, we can affirm that autologous transplants implanted in our RP patients at the ocular level constitute scientific evidence recognized by the aforementioned studies. However, we are aware that we are still in an experimental phase that will have to be deepened with numerous studies. 
Author Contributions: Conceptualization and writing, P.G.L. and M.N.; investigation and formal analysis, C.L.; data curation E.M.V.

Funding: This research received no external funding.

Conflicts of Interest: The authors declare no conflicts of interest.

\section{Abbreviations}

\begin{tabular}{|c|c|}
\hline ADSCs & Adipose tissue-derived stem cells \\
\hline $\mathrm{A} \mu \mathrm{m}^{2}$ & Average of retinal thickness in micron meters \\
\hline BCVA & Best corrected visual acuity \\
\hline BCEA & Bivariate contour ellipse area \\
\hline BDNF & Brain-derived neurotrophic factor \\
\hline bFGF & Basic fibroblast growth factor \\
\hline $\mathrm{C} \mu \mathrm{m}$ & Thickness of central fovea in micron meters \\
\hline CNTF & Ciliary neurotrophic factor \\
\hline $\mathrm{dB}$ & DeciBel \\
\hline EGF & Epidermal growth factor \\
\hline ERG & Electroretinogram \\
\hline ESCs & Embryonic stem cells \\
\hline ETDRS & Early treatment diabetic retinopathy study charts at 4 meters in logMAR \\
\hline FT & Foveal thickness \\
\hline GF & Growth factor \\
\hline IGF-1 & Insulin-like growth factor-1 \\
\hline IL & Interleukin \\
\hline IFN- $\beta$ & Interferon- $\beta$ \\
\hline $\log M A R$ & Logarithm of the minimum angle of resolution \\
\hline iPSCs & Induced pluripotent stem cells \\
\hline ISCEV & International Society for Clinical Electrophysiology of Vision \\
\hline LRRT & Limoli retinal restoration technique \\
\hline MSCs & Mesenchimal stem cells \\
\hline MY & Microperimetry \\
\hline OCT & Optical coherence tomography \\
\hline PDAF & Platelet-derived angiogenesis factor \\
\hline PDGF & Platelet-derived growth factor \\
\hline PEDF & Pigment epithelium-derived factor \\
\hline PlGF & Placental growth factor \\
\hline PLTs & Platelets \\
\hline PRP & Platelet rich plasma \\
\hline pts & Points or print size \\
\hline RdCVF & Rod-cone viability factor \\
\hline RGC & Retinal ganglion cell \\
\hline ROS & Reactive 13 oxygen species \\
\hline $\mathrm{RP}$ & Retinitis pigmentosa \\
\hline RPE & Retinal pigment epithelium \\
\hline SD-OCT & Spectral domain optical coherence tomography \\
\hline SVF & Stromal vascular fraction \\
\hline TGF & Transforming growth factor \\
\hline T0; T180 & Time at baseline; time at 6 months after surgery \\
\hline VEGF & Vascular endothelial growth factor \\
\hline
\end{tabular}

\section{References}

1. Hartong, D.T.; Berson, E.L.; Dryja, T.P. Retinitis pigmentosa. Lancet 2006, 368, 1795-1809. [CrossRef]

2. Hamel, C. Retinitis pigmentosa. Orphanet J. Rare Dis. 2006, 1, 40. [CrossRef] 
3. Birch, D.G.; Anderson, J.L.; Fish, G.E. Yearly rates of rod and cone functional loss in retinitis pigmentosa and cone-rod dystrophy. Ophthalmology 1999, 106, 258-268. [CrossRef]

4. Pagon, R.A. Retinitis pigmentosa. Surv. Ophthalmol. 1988, 33, 137-177. [CrossRef]

5. Campochiaro, P.A.; Mir, T.A. The mechanism of cone cell death in retinitis pigmentosa. Prog. Retin. Eye Res. 2018, 62, 24-37. [CrossRef] [PubMed]

6. Grover, S.; Fishman, G.A.; Alexander, K.R.; Anderson, R.J.; Derlacki, D.J. Visual acuity impairment in patients with retinitis pigmentosa. Ophthalmology 1996, 103, 1593-1600. [CrossRef]

7. McCulloch, D.L.; Marmor, M.F.; Brigell, M.G.; Hamilton, R.; Holder, G.E.; Tzekov, R.; Bach, M. ISCEV Standard for full-field clinical electroretinography. Doc. Ophthalmol. 2015, 130, 1-12. [CrossRef]

8. Liu, G.; Liu, X.; Li, H.; Du, Q.; Wang, F. Optical coherence tomographic analysis of retina in retinitis pigmentosa patients. Ophthalmic Res. 2016, 56, 111-122. [CrossRef]

9. Leveillard, T.; Mohand-Said, S.; Lorentz, O.; Hicks, D.; Fintz, A.C.; Clerin, E.; Simonutti, M.; Forster, V.; Cavusoglu, N.; Chalmel, F.; et al. Identification and characterization of rod-derived cone viability factor. Nat. Genet. 2004, 36, 755-759. [CrossRef]

10. Smith, L.E.H. Bone marrow-derived stem cells preserve cone vision in retinitis pigmentosa. J. Clin. Investig. 2004, 114, 755-757. [CrossRef]

11. Uteza, Y.; Rouillot, J.S.; Kobetz, A.; Marchant, D.; Pecqueur, S.; Arnaud, E.; Prats, H.; Honiger, J.; Dufier, J.L.; Abitbol, M.; et al. Intravitreous transplantation of encapsulated fibroblasts secreting the human fibroblast growthfactor 2 delays photoreceptor cell degeneration in Royal College of surgeons rats. Proc. Natl. Acad. Sci. USA 1999, 96, 3126-3131. [CrossRef] [PubMed]

12. McGee Sanftner, L.H.; Abel, H.; Hauswirth, W.W.; Flannery, J.G. Glial cell line derived neurotrophic factor delays photoreceptor degeneration in a transgenic rat model of retinitis pigmentosa. Mol. Ther. 2001, 4, 622-629. [CrossRef] [PubMed]

13. Bonfiglio, V.; Reibaldi, M.; Fallico, M.; Russo, A.; Pizzo, A.; Fichera, S.; Rapisarda, C.; Macchi, I.; Avitabile, T.; Longo, A. Widening use of dexamethasone implant for the treatment of macular edema. Drug Des. Dev. Ther. 2017, 11, 2359-2372. [CrossRef] [PubMed]

14. Jones, M.K.; Lu, B.; Girman, S.; Wang, S. Cell-based therapeutic strategies for replacement and preservation in retinal degenerative diseases. Prog. Retin. Eye Res. 2017, 58, 1-27. [CrossRef]

15. Otani, A.; Dorrell, M.I.; Kinder, K.; Moreno, S.K.; Nusinowitz, S.; Banin, E.; Heckenlively, J.; Friedlander, M. Rescue of retinal degeneration by intravitreally injected adult bone marrow-derived lineage-negative hematopoietic stem cells. J. Clin. Investig. 2004, 114, 765-774. [CrossRef]

16. Liang, F.Q.; Aleman, T.S.; Dejneka, N.S.; Dudus, L.; Fisher, K.J.; Maguire, A.M.; Jacobson, S.G.; Bennett, J. Long-term protection of retinal structure but not function using RAAV. CNTF in animal models of retinitis pigmentosa. Mol. Ther. 2001, 4, 461-472. [CrossRef]

17. Guadagni, V.; Novelli, E.; Strettoi, E. Environmental enrichment reduces photoreceptor degeneration and retinal inflammation in a mouse model of retinitis pigmentosa. Investig. Ophthalmol. Vis. Sci. 2015, 56, 4261.

18. Idelson, M.; Alper, R.; Obolensky, A.; Ben-Shushan, E.; Hemo, I.; Yachimovich-Cohen, N.; Khaner, H.; Smith, Y.; Wiser, O.; Gropp, M.; et al. Directed differentiation of human embryonic stem cells into functional retinal pigment epithelium cells. Cell Stem. Cell. 2009, 5, 396-408. [CrossRef]

19. Klassen, H. Stem cells in clinical trials for treatment of retinal degeneration. Expert Opin. Biol. Ther. 2015, 16, 7-14. [CrossRef]

20. Takahashi, K.; Yamanaka, S. Induced pluripotent stem cells in medicine and biology. Development 2013, 140, 2457-2461. [CrossRef]

21. Ding, S.L.S.; Kumar, S.; Mok, P.L. Cellular reparative mechanisms of mesenchymal stem cells for retinal diseases. Int. J. Mol. Sci. 2017, 18, 1406. [CrossRef] [PubMed]

22. Romanov, Y.A.; Darevskaya, A.N.; Merzlikina, N.V.; Buravkova, L.B. Mesenchymal stem cells from human bone marrow and adipose tissue: Isolation, characterization, and differentiation potentialities. Bull. Exp. Biol. Med. 2005, 140, 138-143. [CrossRef] [PubMed]

23. Lindroos, B.; Suuronen, R.; Miettinen, S. The potential of adipose stem cells in regenerative medicine. Stem Cell Rev. Rep. 2011, 7, 269-291. [CrossRef] [PubMed]

24. Baddour, J.A.; Sousounis, K.; Tsonis, P.A. Organ repair and regeneration: An overview. Birth Defects Res. C 2012, 96, 1-29. [CrossRef] [PubMed] 
25. Kawamura, A.; Miyagawa, S.; Fukushima, S.; Kawamura, T.; Kashiyama, N.; Ito, E.; Masuda, S.; Toda, K.; Hatazawa, J.; Morii, E.; et al. Teratocarcinomas arising from allogeneic induced pluripotent stem cell-derived cardiac tissue constructs provoked host immune rejection in mice. Sci. Rep. 2016, 6, 19464. [CrossRef]

26. Itakura, G.; Kobayashi, Y.; Nishimura, S.; Iwai, H.; Takano, M.; Iwanami, A.; Toyama, Y.; Okano, H.; Nakamura, M. Controlling immune rejection is a fail-safe system against potential tumorigenicity after human iPSC-derived neural stem cell transplantation. PLoS ONE 2015, 10, e0116413. [CrossRef]

27. Rezanejad, H.; Soheili, Z.S.; Haddad, F.; Matin, M.M.; Samiei, S.; Manafi, A.; Ahmadieh, H. In vitro differentiation of adipose-tissue-derived mesenchymal stem cells into neural retinal cells through expression of human PAX6 (5a) gene. Cell Tissue Res. 2014, 356, 65-75. [CrossRef]

28. Cui, Y.; Xu, N.; Xu, W.; Xu, G. Mesenchymal stem cells attenuate hydrogen peroxide-induced oxidative stress and enhance neuroprotective effects in retinal ganglion cells. Vitr. Cell Dev. Biol. Anim. 2016, 53, 328-335. [CrossRef]

29. Kim, K.S.; Park, J.M.; Kong, T.H.; Kim, C.; Bae, S.H.; Kim, H.W.; Moon, J. Retinal angiogenesis effects of TGF- $\$ 1$ and paracrine factors secreted from human placental stem cells in response to a pathological environment. Cell Transplant. 2016, 25, 1145-1157. [CrossRef]

30. Zhao, P.T.; Zhang, L.J.; Shao, H.; Bai, L.L.; Yu, B.; Su, C.; Dong, L.J.; Liu, X.; Li, X.R.; Zhang, X.M. Therapeutic effects of mesenchymal stem cells administered at later phase of recurrent experimental autoimmune uveitis. Int. J. Ophthalmol. 2016, 9, 1381-1389.

31. Limoli, P.G.; Vingolo, E.M.; Limoli, C.; Scalinci, S.Z.; Nebbioso, M. Regenerative therapy by suprachoroidal cell autograft in dry age-related macular degeneration: Preliminary in vivo report. J. Vis. Exp. 2018, 132, 56469. [CrossRef] [PubMed]

32. Limoli, P.G.; Vingolo, E.M.; Morales, M.U.; Nebbioso, M.; Limoli, C. Preliminary study on electrophysiological changes after cellular autograft in age-related macular degeneration. Medicine 2014, 93, 355. [CrossRef] [PubMed]

33. Limoli, P.G.; Limoli, C.; Vingolo, E.M.; Scalinci, S.Z.; Nebbioso, M. Cell surgery and growth factors in dry age-related macular degeneration: Visual prognosis and morphological study. Oncotarget 2016, 7, 46913-46923. [CrossRef]

34. Limoli, P.G.; Carpi, R.; Tassi, F.; Vingolo, E.M.; D’Amato, L.M.; Giacomotti, E.; Solari, R.; Di Corato, R. Prognostic standard in growth factors teraphy. Investig. Ophthalmol. Vis. Sci. 2012, 53, 277.

35. Bakondi, B.; Girman, S.; Lu, B.; Wang, S. Multimodal delivery of isogenic mesenchymal stem cells yields synergistic protection from retinal degeneration and vision loss. Stem Cells Transl. Med. 2017, 6, 444-457. [CrossRef] [PubMed]

36. Wang, P.; Mariman, E.; Renes, J.; Keijer, J. The secretory function of adipocytes in the physiology of white adipose tissue. J. Cell Physiol. 2008, 216, 3-13. [CrossRef] [PubMed]

37. Trayhurn, P.; Beattie, J.H. Physiological role of adipose tissue: White adipose tissue as an endocrine and secretory organ. Proc. Nutr. Soc. 2001, 60, 329-339. [CrossRef]

38. Tilg, H.; Moschen, A. Adipocytokines: Mediators linking adipose tissue, inflammation and immunity. Nat. Rev. Immunol. 2006, 6, 772-783. [CrossRef]

39. Schaffler, A.; Buchler, C. Concise review: Adipose tissue-derived stromal cells-basic and clinical implications for novel cell-based therapies. Stem Cells 2007, 25, 818-882. [CrossRef]

40. Mizuno, H. Adipose-derived stem cells for tissue repair and regeneration: Ten years of research and a literature review. J. Nippon Med. Sch. 2009, 76, 56-66. [CrossRef]

41. Anitua, E.; Andia, I.; Ardanza, B.; Nurden, P.; Nurden, A.T. Autologous platelets as a source of proteins for healing and tissue regeneration. Thromb. Haemost. 2004, 91, 4-15. [CrossRef] [PubMed]

42. Qureshi, A.H.; Chaoji, V.; Maiguel, D.; Faridi, M.H.; Barth, C.J.; Salem, S.M.; Singhal, M.; Stoub, D.; Krastins, B.; Ogihara, M.; et al. Proteomic and phospho-proteomic profile of human platelets in basal, resting state: Insights into integrin signaling. PLoS ONE. 2009, 4, e7627. [CrossRef] [PubMed]

43. Limoli, P. (Ed.) The retinal cell-neuroregeneration. Principles, applications and perspectives. In Limoli Retina Regeneration Tecnique; FGE Reg. San Giovanni 40: Canelli, Italy, 2014; pp. 159-206.

44. Garcia, T.B.; Hollborn, M.; Bringmann, A. Expression and signaling of NGF in the healthy and injured retina. Cytokine Growth Factor Rev. 2017, 34, 43-57. [CrossRef] [PubMed]

45. Kalucka, J.; Missiaen, R.; Georgiadou, M.; Schoors, S.; Lange, C.; De Bock, K.; Dewerchin, M.; Carmeliet, P. Metabolic control of the cell cycle. Cell Cycle 2015, 14, 3379-3388. [CrossRef] 
46. Mahmoudifar, N.; Doran, P.M. Mesenchymal stem cells derived from human adipose tissue. Methods Mol. Biol. 2015, 1340, 53-64. [CrossRef]

47. Mou, S.; Zhou, M.; Li, Y.; Wang, J.; Yuan, Q.; Xiao, P.; Sun, J.; Wang, Z. Extracellular vesicles from human adipose derived stem cells for the improvement of angiogenesis and fat grafting application. Plast. Reconstr. Surg. 2019, 144, 869-880. [CrossRef]

48. Yu, D.Y.; Cringle, S.J. Retinal degeneration and local oxygen metabolism. Exp. Eye Res. 2005, 80, 745-751. [CrossRef]

49. Punzo, C.; Xiong, W.; Cepko, C.L. Loss of daylight vision in retinal degeneration: Are oxidative stress and metabolic dysregulation to blame? J. Biol. Chem. 2012, 287, 1642-1648. [CrossRef]

50. Campochiaro, P.A.; Strauss, R.W.; Lu, L.; Hafiz, G.; Wolfson, Y.; Shah, S.M.; Sophie, R.; Mir, T.A.; Scholl, H.P. Is there excess oxidative stress and damage in eyes of patients with retinitis pigmentosa? Antioxid. Redox Signal. 2015, 23, 643-648. [CrossRef]

51. Yamada, H.; Yamada, E.; Ando, A.; Esumi, N.; Bora, N.; Saikia, J.; Sung, C.H.; Zack, D.J.; Campochiaro, P.A. Fibroblast growth factor-2 decreases hyperoxia-induced photoreceptor cell death in mice. Am. J. Pathol. 2001, 159, 1113-1120. [CrossRef]

52. Okoye, G.; Zimmer, J.; Sung, J.; Gehlbach, P.; Deering, T.; Nambu, H.; Hackett, S.; Melia, M.; Esumi, N.; Zack, D.J.; et al. Increased expression of brain-derived neurotrophic factor preserves retinal function and slows cell death from rhodopsin mutation or oxidative damage. J. Neurosci. 2003, 23, 4164-4172. [CrossRef] [PubMed]

53. Yang, Y.; Mohand-Said, S.; Danan, A.; Simonutti, M.; Fontaine, V.; Clerin, E.; Picaud, S.; Léveillard, T.; Sahel, J.A. Functional cone rescue by RdCVF protein in a dominant model of retinitis pigmentosa. Mol. Ther. 2009, 17, 787-795. [CrossRef] [PubMed]

54. Aït-Ali, N.; Fridlich, R.; Millet-Puel, G.; Clérin, E.; Delalande, F.; Jaillard, C.; Blond, F.; Perrocheau, L.; Reichman, S.; Byrne, L.C.; et al. Rod-derived cone viability factor promotes cone survival by stimulating aerobic glycolysis. Cell 2015, 161, 817-832. [CrossRef] [PubMed]

55. Byrne, L.C.; Dalkara, D.; Luna, G.; Fisher, S.K.; Clerin, E.; Sahel, J.A.; Leveillard, T.; Flannery, J.G. Viral-mediated RdCVF and RdCVFL expression protects cone and rod photoreceptors in retinal degeneration. J. Clin. Investig. 2015, 125, 105-116. [CrossRef] [PubMed]

56. Gupta, N.; Brown, K.E.; Milam, A.H. Activated microglia in human retinitis pigmentosa, late-onset retinal degeneration, and age related macular degeneration. Exp. Eye Res. 2003, 76, 463-471. [CrossRef]

57. Zeng, H.Y.; Zhu, X.A.; Zhang, C.; Yang, L.P.; Wu, L.M.; Tso, M.O.M. Identification of sequential events and factors associated with microglial activation, migration, and cytotoxicity in retinal degeneration in rd mice. Investig. Ophthalmol. Vis. Sci. 2005, 46, 2992-2999. [CrossRef]

58. Morohoshi, K.; Goodwin, A.M.; Ohbayashi, M.; Ono, S.J. Autoimmunity in retinal degeneration: Autoimmune retinopathy and age related macular degeneration. J. Autoimmun. 2009, 33, 247-254. [CrossRef]

59. Nagineni, C.N.; Samuel, W.; Nagineni, S.; Pardhasaradhi, K.; Wiggert, B.; Detrick, B.; Hooks, J.J. Transforming growth factor-beta induces expression of vascular endothelial growth factor in human retinal pigment epithelial cells: Involvement of mitogen-activated protein kinases. J. Cell Physiol. 2003, 197, 453-462. [CrossRef]

60. Nagineni, C.N.; Kutty, V.; Detrick, B.; Hooks, J.J. Expression of PDGF and their receptors in human retinal pigment epithelial cells and fibroblasts: Regulation by TGF-beta. J. Cell Physiol. 2005, 203, 35-43. [CrossRef]

61. Hooks, J.J.; Nagineni, C.N.; Hooper, L.C.; Hayashi, K.; Detrick, B. IFN-beta provides immuno-protection in the retina by inhibiting ICAM-1 and CXCL9 in retinal pigment epithelial cells. J. Immunol. 2008, 180, 3789-3796. [CrossRef]

62. Di Pierdomenico, J.; García-Ayuso, D.; Agudo-Barriuso, M.; Vidal-Sanz, M.; Villegas-Pérez, M.P. Role of microglial cells in photoreceptor degeneration. Neural Regen. Res. 2019, 14, 1186-1190. [CrossRef] [PubMed]

63. Langmann, T. Microglia activation in retinal degeneration. J. Leukoc. Biol. 2007, 81, 1345-1351. [CrossRef] [PubMed]

64. Boje, K.M.; Arora, P.K. Microglial-produced nitric oxide and reactive nitrogen oxides mediate neuronal cell death. Brain Res. 1992, 587, 250-256. [CrossRef]

65. Yoshida, N.; Ikeda, Y.; Notomi, S.; Ishikawa, K.; Murakami, Y.; Hisatomi, T.; Enaida, H.; Ishibashi, T. Laboratory evidence of sustained chronic inflammatory reaction in retinitis pigmentosa. Ophthalmology 2013, 120, 5-12. [CrossRef] 
66. Lieberthal, W.; Triaca, V.; Koh, J.S.; Pagano, P.J.; Levine, J.S. Role of superoxide in apoptosis induced by growth factor withdrawal. Am. J. Physiol. 1998, 275, 691-702. [CrossRef]

67. Bost, L.M.; Aotaki-Keen, A.E.; Hjelmeland, L.M. Cellular adhesion regulates bFGF gene expression in human retinal pigment epithelial cells. Exp. Eye Res. 1994, 58, 545-552. [CrossRef]

68. Sternfeld, M.D.; Robertson, J.E.; Shipley, G.D.; Tsai, J.; Rosenbaum, J.T. Cultured human retinal pigment epithelial cells express basic fibroblast growth factor and its receptor. Curr. Eye Res. 1989, 8, 1029-1037. [CrossRef]

69. Tanihara, H.; Yoshida, M.; Matsumoto, M.; Yoshimura, N. Identification of transforming growth factor beta expressed in cultured human retinal pigment epithelial cells. Investig. Ophthalmol. Vis. Sci. 1993, 34, 413-419.

70. Slomiany, M.G.; Rosenzweig, S.A. Autocrine effects of IGF-I-induced VEGF and IGFBP-3 secretion inretinal pigment epithelial cell line ARPE-19. Am. J. Physiol. Cell Physiol. 2004, 287, 746-753. [CrossRef]

71. Walsh, N.; Valter, K.; Stone, J. Cellular and subcellular patterns of expression of bFGF and CNTF in the normal and light stressed adult rat retina. Exp. Eye Res. 2001, 72, 495-501. [CrossRef]

72. Campochiaro, P.A.; Sugg, R.; Grotendorst, G.; Hjelmeland, L.M. Retinal pigment epithelial cells produce PDGF-like proteins and secrete them into their media. Exp. Eye Res. 1989, 49, 217-227. [CrossRef]

73. Adamis, A.P.; Shima, D.T.; Yeo, K.T.; Yeo, T.K.; Brown, L.F.; Berse, B.; D’Amore, P.A.; Folkman, J. Synthesis and secretion of vascular permeability factor/vascular endothelial growth factor by human retinal pigment epithelial cells. Biochem. Biophys. Res. Commun. 1993, 193, 631-638. [CrossRef] [PubMed]

74. Wenkel, H.; Streilein, J.W. Evidence that retinal pigment epithelium functions as an immune-privileged tissue. Investig. Ophthalmol. Vis. Sci. 2000, 41, 3467-3473.

75. Szegezdi, E.; Logue, S.E.; Gorman, A.M.; Samali, A. Mediators of endoplasmic reticulum stress-induced apoptosis. EMBO Rep. 2006, 7, 880-885. [CrossRef]

76. Zhang, H.; Wu, F.; Kong, X.; Yang, J.; Chen, H.; Deng, L.; Cheng, Y.; Ye, L.; Zhu, S.; Zhang, X.; et al. Nerve growth factor improves functional recovery by inhibiting endoplasmic reticulum stress-induced neuronal apoptosis in rats with spinal cord injury. J. Transl. Med. 2014, 12, 130. [CrossRef]

77. Ezquer, M.; Urzua, C.A.; Montecino, S.; Leal, K.; Conget, P.; Ezquer, F. Intravitreal administration of multipotent mesenchymal stromal cells triggers a cytoprotective microenvironment in the retina of diabetic mice. Stem Cell Res. Ther. 2016, 7, 42. [CrossRef]

78. Kim, S.Y.; Mocanu, C.; McLeod, D.S.; Bhutto, I.A.; Merges, C.; Eid, M.; Tong, P.; Lutty, G.A. Expression of pigment epithelium-derived factor (PEDF) and vascular endothelial growth factor (VEGF) in sickle cell retina and choroid. Exp. Eye Res. 2003, 77, 433-445. [CrossRef]

79. Atashi, F.; Jaconi, M.E.; Pittet-Cuénod, B.; Modarressi, A. Autologous platelet-rich plasma: A biological supplement to enhance adipose-derived mesenchymal stem cell expansion. Tissue Eng. Part C Methods 2015, 21, 253-262. [CrossRef]

80. Marc, R.E.; Jones, B.W. Retinal remodeling in inherited photoreceptor degenerations. Mol. Neurobiol. 2003, 28, 139-147. [CrossRef]

81. Eysteinsson, T.; Hardarson, S.H.; Bragason, D.; Stefánsson, E. Retinal vessel oxygen saturation and vessel diameter in retinitis pigmentosa. Acta Ophthalmol. 2014, 92, 449-453. [CrossRef]

82. Langham, M.E.; Kramer, T. Decreased choroidal blood flow associated with retinitis pigmentosa. Eye 1990, 4, 374-381. [CrossRef] [PubMed]

83. Beutelspacher, S.C.; Serbecic, N.; Barash, H.; Burgansky-Eliash, Z.; Grinvald, A.; Krastel, H.; Jonas, J.B. Retinal blood flow velocity measured by retinal function imaging in retinitis pigmentosa. Graefe's Arch. Clin. Exp. Ophthalmol. 2011, 249, 1855-1858. [CrossRef] [PubMed]

84. Turksever, C.; Valmaggia, C.; Orgul, S.; Schorderet, D.F.; Flamme, J.; Todorova, M.G. Retinal vessel oxygen saturation and Its correlation with structural changes in retinitis pigmentosa. Acta Ophthalmol. 2014, 92, 454-460. [CrossRef] [PubMed]

85. Ayton, L.N.; Guymer, H.; Luu, C.D. Choroidal thickness profiles in retinitis pigmentosa. Clin. Exp. Ophthalmol. 2013, 41, 396-403. [CrossRef] [PubMed]

86. Murakami, Y.; Ikeda, Y.; Akiyama, M.; Fujiwara, K.; Yoshida, N.; Nakatake, S.; Notomi, S.; Nabeshima, T.; Hisatomi, T.; Enaida, H.; et al. Correlation between macular blood flow and central visual sensitivity in retinitis pigmentosa. Acta Ophthalmol. 2016, 93, 644-648. [CrossRef] [PubMed] 
87. Anitua, E.; Pelacho, B.; Prado, R.; Aguirre, J.J.; Sánchez, M.; Padilla, S.; Aranguren, X.L.; Abizanda, G.; Collantes, M.; Hernandez, M.; et al. Infiltration of plasma rich in growth factors enhances in vivo angiogenesis and improves reperfusion and tissue remodeling after severe hind limb ischemia. J. Control. Release 2015, 202, 31-39. [CrossRef] [PubMed]

88. Mammoto, T.; Jiang, A.; Jiang, E.; Mammoto, A. Platelet rich plasma extract promotes angiogenesis through the angiopoietin1-Tie2 pathway. Microvasc. Res. 2013, 89, 15-24. [CrossRef]

89. Cavallotti, C.; Artico, M.; Pescosolido, N.; Leali, F.M.T.; Feher, J. Age-related changes in the human retina. Can. J. Ophthalmol. 2004, 39, 61-68. [CrossRef]

90. Cervelli, V.; Bocchini, I.; Di Pasquali, C.; De Angelis, B.; Cervelli, G.; Curcio, C.B.; Orlandi, A.; Scioli, M.G.; Tati, E.; Delogu, P.; et al. PRL platelet rich lipotransfert: Our experience and current state of art in the combined use of fat and PRP. Biomed. Res. Int. 2013, 2013, 434191. [CrossRef]

(C) 2019 by the authors. Licensee MDPI, Basel, Switzerland. This article is an open access article distributed under the terms and conditions of the Creative Commons Attribution (CC BY) license (http://creativecommons.org/licenses/by/4.0/). 